\title{
Crop-residue supplementation of pregnant does influences birth weight and weight gain of kids, daily milk yield but not the progesterone profile of Red Sokoto goats
}

\author{
Bunmi Sherifat MALAU-ADULI ${ }^{\mathrm{a}}$, Lawrence EDUVIE ${ }^{\mathrm{b}}$, Clarence LAKPINI $^{\mathrm{b}}$, \\ Aduli Enoch Othniel MALAU-ADULI ${ }^{\mathrm{b}^{*}}$

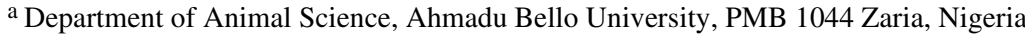 \\ b National Animal Production Research Institute, Ahmadu Bello University, PMB 1096 Zaria, Nigeria
}

(Received 2 July 2003; accepted 20 January 2004)

\begin{abstract}
The parameters investigated in this study with the objective of evaluating growth, lactation and reproductive performances, included birth weight, litter size, 0-90 days gain and average daily gain of kids as well as the milk yield and progesterone profile of Red Sokoto does supplemented with crop-residue based rations during the long-dry period of the subhumid zone in Nigeria. A total of 7 treatments of 4 goats each was utilised. All treatment groups had a basal diet of Digitaria smutsii hay and natural pasture ad libitum. Ration A supplemented with the conventional concentrate was used as the positive control; rations B and C were supplemented with crop residues; and ration D without supplement was used as the negative control. Supplementation with concentrate and crop residues significantly increased $(P<0.05)$ the birth weight and liveweight gains of kids, but littersize was unaffected. The heaviest kids at birth $(1.3-1.4 \mathrm{~kg})$ were from does in treatments $1 \mathrm{~A}$, $2 \mathrm{~A}$ and $2 \mathrm{C}$, while does in treatments $1 \mathrm{~B}, 2 \mathrm{~B}, 1 \mathrm{C}$ and $\mathrm{D}$ had the lightest kids $(1.07-1.18 \mathrm{~kg})$. The highest gains of $53.9 \mathrm{~g} \cdot \mathrm{day}^{-1}$ were recorded in treatment $2 \mathrm{~A}$ and the least $\left(32.4 \mathrm{~g} \cdot \mathrm{day}^{-1}\right)$ in treatment 1B. Supplementation also significantly influenced $(P<0.01)$ the daily milk yield of dams over the 90-day period of the dry season. All the does had similar progesterone profiles from late gestation through parturition to early lactation irrespective of their treatment group. It was concluded that ration $\mathrm{C}$ fed at the $2 \%$ level is a good and affordable supplementary feed package for increased birth weight and preweaning gains in kids for meat production.
\end{abstract}

Red Sokoto goats / supplementation / weight gains / milk / progesterone

\section{INTRODUCTION}

The success of any livestock production enterprise depends largely on adequate and qualitative nutrition. The majority of small ruminant farmers in Nigeria practice the extensive system of management which does not make provision for adequate fee- ding. In the northern region of Nigeria where most of the nation's livestock are concentrated, there is a long and pronounced dry season lasting for six to nine months, often causing serious feed shortages for animals. The prolonged dry season and high temperatures are also accompanied by rapid deterioration in the nutrient

\footnotetext{
* Corresponding author: aduli40@yahoo.co.uk, aduli@affrc.go.jp
} 
quality of available pasture hence, the basic nutritional requirements of the animals during pregnancy or lactation are not met [1]. The majority of Nigerian smallholder goat farmers resort to the easily available, cheap and abundant crop-residues from post-harvest farm operations to feed their animals instead of using the expensive, conventional concentrate ration. These crop residues are also limiting in nutrients necessary for maintenance and production. Therefore, supplementary feeding to boost the nutritional status of the animals has been advocated [2]. However, feed supplementation packages for improving reproductive and lactation performance of small ruminants during the long dry periods of the year are currently not available in Nigeria. Progesterone is the most important reproductive hormone necessary for the initiation and maintenance of pregnancy in female animals. Not much is known about the progesterone profiles of Red Sokoto does during late pregnancy, at parturition and during the early lactation period when the animals are supplemented with crop-residue rations, thus justifying the need for this study and its potential benefit to goat production in Nigeria. Therefore, this study was undertaken to investigate the effect of crop residue supplementation on the birth weight, 0 90 days gain and average daily gains in kids as well as daily milk yield and progesterone profile from late gestation through parturition to early lactation of the Red Sokoto doe.

\section{MATERIALS AND METHODS}

\subsection{Experimental location}

The experiments were conducted in the Experimental Unit of the Small Ruminant Research Programme of the National Animal Production Research Institute, Shika, Zaria, Nigeria. Shika falls between latitudes 11 and $12^{\circ} \mathrm{N}$ and between longitudes 7 and $8^{\circ} \mathrm{E}$, with an altitude of $640 \mathrm{~m}$ above sea level. Shika is located within the North- ern Guinea Savannah Zone with an average annual rainfall and temperature of $1107 \mathrm{~mm}$ and $24.4{ }^{\circ} \mathrm{C}$ respectively. The seasonal distribution of the annual rainfall is approximately $0.1 \%(11.0 \mathrm{~mm})$ in the late-dry season (January-March), 25.8\% (285.6 mm) in the early-wet season (April-June), 69.6\% $(770.4 \mathrm{~mm})$ in the late-wet season (JulySeptember) and $4.5 \%(49.8 \mathrm{~mm})$ in the early dry season (October-December). The experiments were conducted during the dry seasons (between October and March).

\subsection{Crop residue selection and preparation}

The crop residues used in this study were guinea-corn bran, maize offal, cowpea husks, groundnut shells and groundnut haulms as depicted in Table I. They were

Table I. Components of ingredients in the experimental rations.

\begin{tabular}{lcc}
\hline Ration & Ingredients & \% inclusion \\
\hline A + basal diet & Maize & 40.0 \\
& Wheat offal & 35.0 \\
& Cottonseed cake & 20.0 \\
& Bone meal & 3.0 \\
& Salt & 2.0 \\
B + basal diet & Guinea-corn bran & 39.5 \\
& Cowpea husk & 30.0 \\
& G/Nut haulms & 30.0 \\
& Salt & 0.5 \\
C + basal diet & Maize offal & 49.5 \\
& Groundnut & \\
& shells & 20.0 \\
& Groundnut & 30.0 \\
& haulms & 0.5 \\
& Salt & \\
D (basal diet) & Digitaria hay and & ad libitum \\
& natural grazed & \\
& pasture & \\
\hline
\end{tabular}

Ration $\mathrm{A}=$ conventional concentrate (positive control). Ration $\mathrm{B}=$ crop-residue test ration 1 . Ration $\mathrm{C}=$ crop-residue test ration 2. D = unsupplemented group (negative control) that was the basal diet common to all treatments. 
selected because they were easily available, abundant, cheap and easy to process. These residues were bought in bulk from an open market. To aid consumption and digestibility, the groundnut shells were crushed before inclusion into the ration. All the crop residues were stored in a well-ventilated barn and required amounts compounded every fortnight to maintain freshness.

\subsection{Animals, experimental rations and management}

Twenty-eight adult Red Sokoto does with an average liveweight of $28 \pm 3.5 \mathrm{~kg}$ were used for this study. Besides the negative control, the other treatments consisting of three experimental rations (A, B, C) and 2 feeding levels ( 1 and $2 \%$ of body weight) for each ration were arranged as a $3 \times 2$ factorial design. Thus, a total of 7 treatments of 4 goats each were utilized after balancing the animals for weight. All treatment groups had a basal diet of Digitaria smutsii hay and natural pasture ad libitum. Ration A the conventional concentrate ration, was used as the positive control, rations $\mathrm{B}$ and $\mathrm{C}$ were the two crop residue based test rations, while ration $\mathrm{D}$ the unsupplemented treatment, was used as the negative control. Does in treatment $1 \mathrm{~A}$ had conventional concentrate at $1 \%$ of their body weight, those in treatment $2 \mathrm{~A}$ also had conventional concentrate but at $2 \%$ of their body weight. Animals in treatments $1 \mathrm{~B}, 2 \mathrm{~B}, 1 \mathrm{C}$ and $2 \mathrm{C}$ were those fed the two crop-residue test rations $\mathrm{B}$ and $\mathrm{C}$ at $1 \%$ and $2 \%$ of body weight respectively. In terms of management, all animals were routinely dewormed with anthelmintic drugs (Ivomec and thiabendazole) and dipped in an acaricide (Asuntol) solution against ectoparasites. The animals were fed for two hours each day between $08.00-10.00 \mathrm{~h}$ with the appropriate ration. Feed was weighed before offering it to individual animals. The left-over was again weighed at the end and the difference between what was offered and the residual was taken as feed intake. Thereafter, they were released into a specified paddock to graze natural pastures and Digitaria smutsii hay ad libitum under the supervision of a herdsman until $18.00 \mathrm{~h}$. The animals were housed in well-ventilated pens during the night. The rations in all the groups were subjected to digestibility trials prior to being fed to the experimental animals as described below.

\subsection{Digestibility measurement}

Red Sokoto does $(n=28)$ ranging between 24.6 and $26.4 \mathrm{~kg}$ were used for the digestibility trial. Each doe was individually offered its appropriate corresponding ration to evaluate the digestibility of the diets. The study comprised a two-week preliminary period of realimentation and adjustment, and one week of sample collection. The animals were housed in individual metabolism cages with facilities for separate collection of faeces and urine. The animals were weighed at the beginning and end of the study. The faeces were collected each morning just before feeding. Ten per cent of each daily faecal output was collected from which sub-samples were bulked for chemical analyses. Samples of the different rations fed were taken daily and bulked, from which sub-samples were taken for laboratory analysis. Also, samples of the individual feed ingredients were analysed in the laboratory. Water was made available to the animals ad libitum. The inventory, abundance and palatability of the plant species in the grazed paddock has been described by Lakpini et al. [3].

\subsection{Kid weight and milk sampling}

The animals were fed from the last trimester of pregnancy to parturition. At parturition, the doe and its kid(s) were separated and placed in individual pens. The kids were weighed within $8 \mathrm{~h}$ after birth and subsequently once every week until they were weaned. Dams were also weighed weekly starting from 20 days postpartum, until the end of the study. Measurements for milk yield commenced from day 7 postpartum to allow kids have access to all their 
dams' colostrum. The two halves of the udder of each lactating doe were handmilked early in the morning. The quantity of milk collected at each milking was recorded and the does were monitored from a week after delivery to the last day of milk let-down when the total lactation length was recorded. Milk samples were collected twice daily (morning and evening) from 7 days postpartum to 90 days after parturition.

\subsection{Blood sampling}

Blood samples $(10 \mathrm{~mL})$ for the progesterone assay were collected from each doe by jugular venipuncture twice a week during the last trimester of pregnancy. The blood samples were allowed to clot within two hours of collection and the sera were decanted into plastic tubes and stored at $-20{ }^{\circ} \mathrm{C}$ until analysis.

\subsection{Chemical analyses}

Proximate analyses of feed and faecal samples were carried out by the AOAC methods [4]. Dry matter of samples was determined in an oven at $105^{\circ} \mathrm{C}$ for $48 \mathrm{~h}$. Nitrogen determination was by the Micro Kjedahl method, while the Soxhlet extraction procedure was used for ether extraction. Crude fibre was determined by alternate refluxing with weak solutions of $\mathrm{H}_{2} \mathrm{SO}_{4}$ and $\mathrm{KOH}$. The detergent fibre fractions (neutral detergent fibre, acid detergent fibre and lignin) were determined according to Goering and Van Soest [5].

\subsection{Hormonal assay of sera and milk samples}

Progesterone concentration in the sera and milk samples was determined by the radio-immunoassay procedure using the solid phase coated tube system employing ${ }^{125} \mathrm{I}$ as the tracer supplied in a kit form by the Joint FAO/IAEA Division, Agriculture Laboratory, Siebersdof. The assay procedure was as follows: the standard $(100 \mu \mathrm{L})$ was added to antibody tubes containing $(0.1$ to $40 \mathrm{ng} \cdot \mathrm{mL}^{-1}$ ) of the sample and $1 \mathrm{~mL}$ buffered $\left[{ }^{125} \mathrm{I}\right]$ labelled progesterone solution. The mixture was incubated for $3 \mathrm{~h}$ at room temperature, the liquid phase was discarded (centrifugation is not required) and the radioactivity bound to the antibody-coated tube was counted. The immunogen used to raise the antibody and radioiodinated progesterone (tyrosine methyl ester) are both $11 \alpha$ linked conjugates. The cross-reactivity, 3.8\%, was with $11 \alpha$-hydroxy progesterone [6]. The sensitivity of the assay defined as twice the standard deviations away from the zero standard was $0.08 \mathrm{ng} \cdot \mathrm{mL}^{-1}$. The within and between assay coefficients of variation were $8.5 \%$ and $9.5 \%$ respectively. The potencies of the samples were estimated using a linear logit-log dose response curve.

\subsection{Calculations and statistical analysis}

Dry matter intake (DMI) was determined using the following equation:

DMI $\left(\mathrm{g} \cdot\right.$ day $\left.^{-1}\right)=\%$ DM/100 $\times$ feed intake

Dry matter digestibility (DMD (\%)) was calculated as:

$100 \times[\mathrm{DM}$ intake $(\mathrm{g})-\mathrm{DM}$ output $(\mathrm{g})] \cdot \mathrm{DM}^{-1}$ intake $\left.(\mathrm{g})\right]$. The other digestibilities were calculated as above. Data on kid birth weight and weight gains, dam's daily milk yield and peripheral progesterone concentrations were statistically analysed using the general linear models procedure (PROC GLM) of SAS [7] in a $3 \times 2$ factorial (3 rations and 2 feeding levels) analysis to test for significant differences between the means. The model below was utilised:

$\begin{aligned} Y_{i j k}= & \mu+R_{i}+F_{j}+(R F)_{i j}+b_{1}\left(w_{i j k}-w\right) \\ & +e_{i j k}\end{aligned}$

where $Y_{i j k}=$ dependent variable of the kth doe on the ith ration and the jth feeding level, $\mu=$ the overall mean, $R_{i}=$ fixed effect of the ith ration $(I=1,3), F_{j}=$ fixed effect of the $\mathrm{jth}$ feeding level $(\mathrm{j}=1,2),(R F)_{i j}=$ interaction between the ith ration and $j$ th 
Table II. Chemical composition of the major feed ingredients (DM basis) (\%).

\begin{tabular}{lcccccc}
\hline $\begin{array}{l}\text { Feedstuff } \\
(n=7 \text { samples/ingredient each })\end{array}$ & DM & CP & CF & Ash & EE & NFE \\
\hline Maize & 90.73 & 9.56 & 2.20 & 9.67 & 4.05 & 74.52 \\
Wheat offal & 87.60 & 16.90 & 11.30 & 6.40 & 3.80 & 61.60 \\
Cottonseed cake & 93.60 & 29.94 & 23.50 & 5.16 & 5.76 & 35.64 \\
Bone meal & 75.00 & 36.00 & 3.00 & 49.00 & 4.00 & 8.00 \\
Guinea corn bran & 93.33 & 7.60 & 24.80 & 6.95 & 3.01 & 59.90 \\
Cowpea husks & 91.41 & 7.10 & 33.40 & 7.14 & 0.65 & 58.91 \\
Groundnut haulms & 93.65 & 15.63 & 23.26 & 8.00 & 2.43 & 51.00 \\
Maize offal & 89.07 & 10.08 & 1.50 & 0.80 & 1.70 & 60.30 \\
Groundnut shells & 96.05 & 5.90 & 31.80 & 8.50 & 1.31 & 50.30 \\
\hline
\end{tabular}

$\mathrm{DM}=$ dry matter, $\mathrm{CP}=$ crude protein, $\mathrm{CF}=$ crude fibre, $\mathrm{EE}=$ ether extract, $\mathrm{NFE}=$ nitrogen-free extracts.

feeding level, $b_{1}=$ partial regression coefficient of initial body weight with mean w-, $\mathrm{w}=$ initial body weight fitted as a covariate, $\mathrm{e}_{\mathrm{ijk}}=$ random error associated with each record with a mean of 0 and variance $\sigma^{2}$.

Primary and secondary interactions of fixed effects with initial body weight were also tested but later dropped from the model since all the interactions were not significant, mainly because all the animals were as much as possible, balanced for initial weight and age at the start of the experiment. The contrast option of the Tukey test was used for mean separation where significant differences $(P<0.05)$ were established between the treatments.

\section{RESULTS}

\subsection{Feed intake and digestibility}

Tables I, II, III and IV show the component of ingredients, chemical composition of the major feed ingredients, chemical composition of the experimental diets and their digestibilities respectively. Ration A had the highest crude protein (CP) of $17.19 \%$, rations $\mathrm{B}$ and $\mathrm{C}$ had 9.54 and $10.38 \%$ respectively, while ration D had the least with Digitaria smutsii hay and natural grazed pastures having 4.75 and $2.76 \%$ respectively (Tab. III). There were differences $(P<0.05)$ in nutrient intake, digestibility and cost of feeds between the different treatment groups (Tab. IV). The table shows that generally, the supplemented groups had significantly higher $(P<0.05)$ $\mathrm{DM}$ and $\mathrm{CP}$ intakes and digestibilities than the unsupplemented group except animals on ration $B$ that had similar values to the unsupplemented group. It was also evident that increasing the level of supplementation also resulted in increased DM and $\mathrm{CP}$ intakes of all the experimental rations, with these increases being significant $(P<0.05)$ and similar for rations $\mathrm{A}$ and $\mathrm{C}$. It was also observed that supplementation increased the digestibility of all the nutrients. However, the animals on ration B recorded very poor digestibility values and their counterparts in the unsupplemented group had the lowest values. Ration 1A (the conventional concentrate at a $1 \%$ body weight) gave the highest digestibility values; a comparison of the unsupplemented animals with all the other treatment groups reveals that DM digestibility improved by a range of 4.1 to $27.9 \%$ and CP digestibility by 17.1 to $42.2 \%$, 
Table III. Chemical composition of the experimental diets (dry matter basis) (\%).

\begin{tabular}{lcrrrrrc}
\hline $\begin{array}{l}\text { Ration } \\
(n=7 \text { samples/ration each) }\end{array}$ & DM & CP & Ash & EE & ADF & NDF & LIGNIN \\
\hline Ration A & 93.87 & 17.19 & 13.85 & 14.08 & 20.00 & 40.01 & 4.64 \\
Ration B & 94.97 & 9.54 & 10.55 & 10.43 & 38.10 & 68.42 & 8.94 \\
Ration C & 95.94 & 10.38 & 11.97 & 12.45 & 36.65 & 54.74 & 8.23 \\
Ration D (Hay) & 94.78 & 4.75 & 8.47 & 2.40 & 49.14 & 74.73 & 9.49 \\
Ration D (Natural pastures) & 96.26 & 2.76 & 7.02 & 0.78 & 50.29 & 80.27 & 11.50 \\
\hline
\end{tabular}

Calculated analysis of the experimental rations.

\begin{tabular}{lccc}
\hline & Ration A & Ration B & Ration C \\
$\mathrm{CP}(\%)$ & 17.05 & 9.82 & 10.85 \\
$\mathrm{ME}\left(\mathrm{MJ} \cdot \mathrm{kg}^{-1} \mathrm{DM}\right)$ & 11.17 & 10.29 & 10.17 \\
\hline
\end{tabular}

The ME values of the experimental rations were calculated as per Alderman [27] as follows: $\mathrm{ME}\left(\mathrm{MJ}^{\mathrm{k}} \cdot \mathrm{kg}^{-1}\right.$ $\mathrm{DM})=11.78+0.00654 \mathrm{CP}+(0.000665 \mathrm{EE})^{2}-\mathrm{CF}(0.00414 \mathrm{EE})-0.0118 \mathrm{~A}$ where $\mathrm{CP}=$ crude protein, $\mathrm{EE}=$ ether extract, $\mathrm{CF}=$ crude fibre, $\mathrm{A}=$ ash. $\mathrm{DM}=$ dry matter, $\mathrm{ADF}=$ acid detergent fibre, $\mathrm{NDF}=$ neutral detergent fibre.

Table IV. Mean nutrient intake, apparent digestibility and cost of the experimental diets.

\begin{tabular}{|c|c|c|c|c|c|c|c|c|}
\hline Treatment & $1 \mathrm{~A}$ & $2 \mathrm{~A}$ & $1 \mathrm{~B}$ & $2 \mathrm{~B}$ & $1 \mathrm{C}$ & $2 \mathrm{C}$ & $\mathrm{D}$ & SEM \\
\hline \multicolumn{9}{|c|}{ Nutrient intake $\left(\mathrm{kg} \cdot \mathrm{day}^{-1}\right)$} \\
\hline DM & $0.24^{\mathrm{b}}$ & $0.47^{\mathrm{a}}$ & $0.21^{\mathrm{b}, \mathrm{c}}$ & $0.30^{\mathrm{a}, \mathrm{b}}$ & $0.23^{\mathrm{b}}$ & $0.42^{\mathrm{a}}$ & $0.15^{\mathrm{c}}$ & \pm 0.02 \\
\hline $\mathrm{CP}$ & $0.044^{\mathrm{a}}$ & $0.087^{\mathrm{a}}$ & $0.012^{b}$ & $0.017^{b}$ & $0.032^{\mathrm{a}}$ & $0.072^{\mathrm{a}}$ & $0.009^{b}$ & \pm 0.01 \\
\hline \multicolumn{9}{|c|}{ Apparent digestibility of nutrients $(\%)$} \\
\hline $\mathrm{DM}$ & $84.3^{\mathrm{a}}$ & $83.0^{\mathrm{a}}$ & $62.5^{\mathrm{d}}$ & $60.5^{\mathrm{e}}$ & $75.8^{\mathrm{b}}$ & $67.8^{c}$ & $56.4^{\mathrm{f}}$ & \pm 2.8 \\
\hline $\mathrm{CP}$ & $90.6^{\mathrm{a}}$ & $89.2^{\mathrm{a}}$ & $69.5^{\mathrm{d}}$ & $65.5^{\mathrm{e}}$ & $82.7^{b}$ & $78.1^{\mathrm{c}}$ & $48.4^{\mathrm{f}}$ & \pm 3.1 \\
\hline $\mathrm{NDF}$ & $69.5^{\mathrm{a}}$ & $66.6^{\mathrm{b}}$ & $62.1^{\mathrm{c}, \mathrm{d}}$ & $61.9^{d}$ & $65.9^{\mathrm{b}}$ & $63.7^{c}$ & $60.1^{\mathrm{e}}$ & \pm 3.2 \\
\hline $\mathrm{ADF}$ & $51.7^{\mathrm{a}}$ & $49.8^{\mathrm{a}}$ & $43.9^{\mathrm{b}, \mathrm{c}}$ & $42.8^{c}$ & $46.1^{\mathrm{b}}$ & $44.4^{\mathrm{b}, \mathrm{c}}$ & $42.3^{\mathrm{b}, \mathrm{c}}$ & \pm 5.0 \\
\hline \multicolumn{9}{|c|}{ Economic analysis of the feeds (Naira)* } \\
\hline $\begin{array}{l}\text { Cost of feed } \\
\text { consumed } \\
\text { per day }\end{array}$ & $2.19^{\mathrm{b}}$ & $4.42^{\mathrm{a}}$ & $0.50^{\mathrm{e}}$ & $1.06^{\mathrm{d}}$ & $0.83^{\text {de }}$ & $1.55^{\mathrm{c}}$ & - & \pm 0.15 \\
\hline
\end{tabular}

a,b,c,d,e,f Means within the same row bearing different superscript letters differ significantly $(P<0.05)$. * Naira = Nigerian currency (100 kobo make 1 naira and current exchange rate is 1 US\$ $=140$ naira). DM $=$ dry matter, $\mathrm{CP}=$ crude protein, $\mathrm{NDF}=$ neutral detergent fibre, $\mathrm{ADF}=$ acid detergent fibre. Treatment: $1 \mathrm{~A}=$ ration $\mathrm{A}$ (conventional concentrate) offered at $1 \%$ of body weight. $2 \mathrm{~A}=$ ration $\mathrm{A}$ (conventional concentrate) offered at $2 \%$ of body weight. $1 \mathrm{~B}=$ crop-residue test ration $\mathrm{B}$ offered at $1 \%$ of body weight. $2 \mathrm{~B}=$ crop-residue test ration $\mathrm{B}$ offered at $2 \%$ of body weight. $1 \mathrm{C}=$ crop-residue test ration $\mathrm{C}$ offered at $1 \%$ of body weight. $2 \mathrm{C}=$ crop-residue test ration $\mathrm{C}$ offered at $2 \%$ of body weight. $\mathrm{D}=$ unsupplemented group. 
Table V. Effect of ration supplementation of Red Sokoto does on daily milk yield, littersize, birth weight, 0-90 days weight gain and average daily gains of their kids ( \pm SEM).

\begin{tabular}{lccccccc}
\hline Ration & $\begin{array}{c}\text { Dam's milk } \\
\text { yield }\left(\mathrm{kg} \cdot \mathrm{day}^{-1}\right)\end{array}$ & Littersize & $\begin{array}{c}\text { BWT } \\
(\mathrm{kg})\end{array}$ & $\begin{array}{c}\text { WT30 } \\
(\mathrm{kg})\end{array}$ & $\begin{array}{c}\text { WT60 } \\
(\mathrm{kg})\end{array}$ & $\begin{array}{c}\text { WT90 } \\
(\mathrm{kg})\end{array}$ & $\begin{array}{c}\text { ADG } \\
\left(\mathrm{g} \cdot \mathrm{day}^{-1}\right)\end{array}$ \\
\hline $1 \mathrm{~A}$ & $0.48^{\mathrm{b}}$ & 1.34 & $1.3^{\mathrm{a}}$ & $2.33^{\mathrm{b}}$ & $3.50^{\mathrm{b}}$ & $5.54^{\mathrm{a}, \mathrm{b}}$ & $47.11^{\mathrm{b}}$ \\
$2 \mathrm{~A}$ & $0.62^{\mathrm{a}}$ & 1.32 & $1.4^{\mathrm{a}}$ & $3.30^{\mathrm{a}}$ & $4.70^{\mathrm{a}}$ & $6.25^{\mathrm{a}}$ & $53.88^{\mathrm{a}}$ \\
$1 \mathrm{~B}$ & $0.27^{\mathrm{d}}$ & 1.34 & $1.09^{\mathrm{b}}$ & $1.95^{\mathrm{b}}$ & $3.09^{\mathrm{b}}$ & $4.01^{\mathrm{c}}$ & $32.44^{\mathrm{d}}$ \\
$2 \mathrm{~B}$ & $0.36^{\mathrm{c}}$ & 1.30 & $1.07^{\mathrm{b}}$ & $2.04^{\mathrm{b}}$ & $3.05^{\mathrm{b}}$ & $4.33^{\mathrm{c}}$ & $36.11^{\mathrm{c}}$ \\
$1 \mathrm{C}$ & $0.60^{\mathrm{a}}$ & 1.31 & $1.11^{\mathrm{b}}$ & $2.55^{\mathrm{b}}$ & $3.85^{\mathrm{a}, \mathrm{b}}$ & $5.88^{\mathrm{a}, \mathrm{b}}$ & $53.00^{\mathrm{a}}$ \\
$2 \mathrm{C}$ & $0.45^{\mathrm{b}}$ & 1.32 & $1.34^{\mathrm{a}}$ & $2.20^{\mathrm{b}}$ & $3.45^{\mathrm{b}}$ & $5.33^{\mathrm{b}}$ & $44.33^{\mathrm{b}}$ \\
$\mathrm{D}$ & $0.25^{\mathrm{d}}$ & 1.31 & $1.18^{\mathrm{b}}$ & $1.88^{\mathrm{b}}$ & $2.98^{\mathrm{c}}$ & $4.16^{\mathrm{c}}$ & $33.11^{\mathrm{d}}$ \\
SEM & \pm 0.02 & \pm 0.09 & \pm 0.16 & \pm 0.21 & \pm 0.30 & \pm 0.27 & \pm 0.17 \\
\hline
\end{tabular}

Column means bearing different superscripts differ from each other significantly $(P<0.01)$. BWT $=$ birth weight, WT30, WT60, WT90 are liveweights at 30,60 and 90 days, ADG = average daily gain. Ration symbols as described in Table IV.

the highest being in animals on ration $1 \mathrm{~A}$. Similar improvement trends were also noticeable for neutral detergent fibre (NDF) and acid detergent fibre (ADF). A simple economic analysis (Tab. IV) revealed that the conventional concentrate feed was the most expensive for supplementation particularly at the $2 \%$ level (4.42 naira per animal per day). Amongst the two tested crop-residue rations, ration $1 \mathrm{~B}$ was significantly cheaper $(P<0.05)$ than rations $2 \mathrm{~B}$ and $2 \mathrm{C}$, but similar to ration $1 \mathrm{C}$.

\subsection{Influence of supplementation on kid birth weight and weight gains, littersize and milk yield}

Portrayed in Table $\mathrm{V}$ is evidence that there was a highly significant $(P<0.01)$ effect of feed supplementation during gestation on the birth weight of kids whereas litter size was unaffected $(P>0.05)$. Does on ration $2 \mathrm{~A}$ had the heaviest kids $(1.4 \mathrm{~kg})$ at birth, followed by kids whose dams were fed ration $2 \mathrm{C}(1.34 \mathrm{~kg})$. Does on ration $2 \mathrm{~B}$ had the lightest kids at birth $(1.07 \mathrm{~kg})$ but this was not significantly different from the birth weights of kids whose dams were fed rations $1 \mathrm{~B}, 1 \mathrm{C}$ and $\mathrm{D}$. It was also evident that supplementation significantly $(P<0.001)$ increased dam's daily milk yield in that does on ration $2 \mathrm{~A}$ gave $0.62 \mathrm{~kg}$ of milk per day (not significantly different from the $0.60 \mathrm{~kg} \cdot \mathrm{day}^{-1}$ from does on ration $1 \mathrm{C}$ ), compared to the lowest milk yield of $0.25 \mathrm{~kg} \cdot \mathrm{day}^{-1}$ from the unsupplemented does (ration D). There were significant differences in the liveweights and gains of kids as they advanced in age. At 30 days of age (WT30), kids of does fed ration 2A were significantly $(P<0.01)$ heavier than all the others. This weight advantage was consistently maintained from 60 (WT60) to 90 (WT90) days of age with kids weighing 4.70 and $6.25 \mathrm{~kg}$ respectively. This superiority over the other treatment groups was also reflected in the average daily gain (ADG) of $53.88 \mathrm{~g}$. However, kids from does fed crop-residue test rations $1 \mathrm{C}$ ranked next with WT30, WT60, WT90 and ADG values of $2.55,3.85,5.88 \mathrm{~kg}$ and $53.00 \mathrm{~g} \cdot \mathrm{day}^{-1}$ respectively. It was also consistently evident that kids from dams that were unsupplemented (ration D) and those fed crop-residue test rations $1 \mathrm{~B}$ and $2 \mathrm{~B}$ recorded the least weights and average daily gains. 
Table VI. Progesterone concentration (ng $\cdot \mathrm{mL}^{-1}$ ) during late gestation, pre-partum, at parturition and post-partum $( \pm$ SEM) in Red Sokoto does supplemented with crop residue rations.

\begin{tabular}{lcccc}
\hline Ration & $\begin{array}{c}\text { Late gestation } \\
(\text { day 120-day 140) }\end{array}$ & $\begin{array}{c}\text { Pre-partum } \\
\text { (day 6-day 2) }\end{array}$ & $\begin{array}{c}\text { Parturition } \\
\text { (day 0) }\end{array}$ & $\begin{array}{c}\text { Post-partum } \\
\text { (day 1-day 15) }\end{array}$ \\
\hline 1A & 13.03 & 8.90 & 0.09 & 0.17 \\
2A & 12.98 & 9.06 & 0.09 & 0.16 \\
1B & 13.04 & 9.05 & 0.11 & 0.20 \\
2B & 12.98 & 8.92 & 0.09 & 0.18 \\
1C & 12.92 & 8.94 & 0.09 & 0.19 \\
2C & 12.88 & 9.04 & 0.10 & 0.17 \\
D & 13.05 & 8.98 & 0.10 & 0.18 \\
SEM & \pm 0.45 & \pm 0.22 & \pm 0.05 & \pm 0.11 \\
\hline
\end{tabular}

\subsection{Progesterone profile}

Hormonal assay results shown in Table VI and Figure 1 reveal that right from late gestation through parturition to early lactation, the progesterone profile was remarkably similar for all does irrespective of treatment groups. The progesterone $\left(\mathrm{P}_{4}\right)$ concentrations were quite high in late gestation with an average value of $13 \mathrm{ng} \cdot \mathrm{mL}^{-1}$ (Tab. VI) and the highest value of $17.08 \mathrm{ng} \cdot \mathrm{mL}^{-1}$ at day 140 . At parturition, the $\mathrm{P}_{4}$ concentration dropped sharply to an average of $0.10 \mathrm{ng} \cdot \mathrm{mL}^{-1}$, then rose slowly in early lactation to $0.18 \mathrm{ng} \cdot \mathrm{mL}^{-1}$. However, there were no significant supplementation effects on progesterone profiles of the does.

\section{DISCUSSION}

\subsection{Ration intake and digestibility}

The preponderance of crop residues in rations $\mathrm{B}$ and $\mathrm{C}$ was responsible for their high crude fibre and lignin levels compared to the conventional concentrate ration A. The current study showed that even though rations $\mathrm{B}$ and $\mathrm{C}$ were isocaloric and isonitrogenous, the animals on ration $\mathrm{C}$ had better intakes and digestibilities than those on ration $\mathrm{B}$, possibly due to the low palatability, hence low voluntary intake, and poor digestibility of ration $\mathrm{B}$.
The observed higher digestibilities of DM, CP, NDF and ADF at the $1 \%$ level in comparison to the $2 \%$ level can be attributed to the higher feed intake at the $2 \%$ level of inclusion. It has been established that higher feed intake results in a faster rate of passage of digesta from the reticulo-rumen [8]. This does not allow for effective degradation, hence lowering the digestibility of feed. Increasing the level of crop residue inclusion in the diet also increases the amount of lignin, which depresses the digestibility of the ration [9], because the rate of microbial colonisation of a feed with high fibre content is comparatively lower [10]. The poor intake and digestibility values obtained for the unsupplemented animals is due to the fact that ration D was of low quality as a result of its high NDF and lignin contents. This shows that there is the need for dry season supplementation in goats because the available feeds at that time are limiting in crude protein.

Amongst the two tested rations, ration $\mathrm{C}$ seemed to have produced better intakes and digestibilities in the animals, possibly due to the composition of the rations. It contained maize offal which has very low fibre content [2], groundnut haulms which have been demonstrated to be better quality roughages than Digitaria smutsii hay and contain adequate protein to maintain ruminants without any form of supplementation 
during the periods of feed scarcity [11]. The groundnut shells fed to the animals were also crushed before inclusion into the ration as earlier stated. This must have aided their consumption and digestibility. Even though ration B contained groundnut haulms, the combination of Guinea corn bran and cowpea husk which had low crude protein percentages, must have reduced the intake and digestibility of the ration. Alhassan et al. [12] observed lower digestibility values in sheep and goats (48.8 and 56.3\% respectively) compared with cattle $(73.6 \%)$ when they fed them cowpea vines. This might imply that cattle do better on cowpea residues than small ruminants. Generally speaking, digestibility of feeds in cattle is lower than that in sheep or goats under similar conditions because of the higher rate of passage from the rumen in cattle than sheep or goats. From the economic analysis, the high cost of the conventional concentrate ration shows that it is beyond the reach of a typical smallholder goat farmer; whereas the cropresidue based rations seem quite affordable. Even though ration B had the lowest cost, it was clear that it had lower intake and digestibility compared to ration $\mathrm{C}$, indicating in essence, that ration $\mathrm{C}$ had a better efficiency of utilisation.

\subsection{Birth weight and weight gains of kids}

The importance of supplementation during the last lap of pregnancy was confirmed in this study with does on ration $2 \mathrm{~A}$ producing the heaviest kids at parturition compared to the unsupplemented does (ration D) having the lightest kids at birth. However, dams fed ration $1 \mathrm{~A}$ and $2 \mathrm{C}$ also had kids with birth weights similar to those of ration $2 \mathrm{~A}$.

The growth rate of kids was influenced by the type of ration offered to their dams during lactation, and the average daily gain was found to be the lowest (32.44 g.day ${ }^{-1}$ ) in kids from dams fed ration $1 \mathrm{~B}$ and highest in ration $2 \mathrm{~A}\left(53.88 \mathrm{~g} \cdot \mathrm{day}^{-1}\right)$. As the kids advanced in age from birth to 90 days, the effect of dam supplementation was reflec- ted in their liveweight gains in agreement with the report of Ahmed et al. [13]. The highest ADG value of $53.88 \mathrm{~g} \cdot \mathrm{day}^{-1}$ in this study fell within the range of $64 \mathrm{~g} \cdot \mathrm{day}^{-1}$ reported in West African Dwarf does [1416], but much lower than $150 \mathrm{~g} \cdot \mathrm{day}^{-1}$ in Yankasa lambs [17]. The lower values in this study are justifiable given the fact that it was conducted in the long-dry season of the year when naturally grazed pasture and feed resources are critically low. The average littersize of 1.3 reported herein was similar to the findings of Adu et al. [1]. The observation that supplementation did not affect littersize agreed with that of Sibanda et al. [18], indicating that littersize may be controlled more by genetic, rather than nutritional, factors.

The effects of various crop residues on feed intake, liveweight gains and growth performance of ruminants have been reported by Adu and Lakpini $[19,20]$ and Ikhatua and Adu [11]. Adu and Lakpini [20] obtained liveweight gains of $90.2 \mathrm{~g} \cdot \mathrm{day}^{-1}$ in Yankasa lambs fed a sole diet of unchopped groundnut haulms. In the study by Ikhatua and Adu [11], supplementation of groundnut haulms with concentrate further enhanced the intake and performance of the animals. Similar effects of supplementation were observed in this study.

The observation that birth weight in ration $2 \mathrm{C}$ was higher than that of $1 \mathrm{C}$ but the subsequent growth thereafter was reversed (Tab. V) was probably a result of the incidence of scouring (diarrhea) that occurred in kids on ration $2 \mathrm{C}$. The weight losses observed in does fed rations $1 \mathrm{~B}$ and $\mathrm{D}$ could be attributed to the low palatability, low intake and poor digestibility of the feeds.

\subsection{Daily milk yield of dams}

This study also confirmed that the milk yield of does can be improved by supplementing their pasture diets with some concentrates [21]. The observed values of daily milk yield in does fed rations $2 \mathrm{~A}$ and $1 \mathrm{C}$ were higher than those reported by Adu 
et al. [1], Akinsoyinu et al. [22] and Ehoche and Buvanendran [16]. This increase in milk yield may be due to improvement as a result of selection over the years within the Red Sokoto breed. The inference that can be drawn from this observation is that feeding lactating does ration $1 \mathrm{C}$ irrespective of the fact that it is mainly a crop residue ration, gives just as good a result in terms of daily milk yields, as full concentrate rations. This holds hope for smallholders interested in improving the milk yield of their Red Sokoto dams without necessarily embarking on an expensive concentrate ration. It was expected that ration $2 \mathrm{C}$ with a higher dry matter intake in comparison with ration $1 \mathrm{C}$ (Tab. IV) would give a higher milk yield, but the reverse was the case (Tab. V). The reason is because the fat content of the milk from does on ration $2 \mathrm{C}$ was higher than that of does on ration $1 \mathrm{C}[23,24]$. There is an inverse relationship between total milk yield and fat content in lactating animals [25] which explains why this trend was observed. This suggests that if Nigerian goat producers in the subhumid zone intend to place more emphasis on total milk yield rather than on fat content of the milk, then going by our results in this study, ration $\mathrm{C}$ fed at the $1 \%$ level of inclusion is better than at the $2 \%$ level.

\subsection{Progesterone profile during late pregnancy, at parturition and early lactation}

This study indicated that the level of supplementation does not affect the progesterone profile and concentration from the last trimester of gestation to early lactation (Tab. VI). This may mean that the endocrine system is resilient to nutritional stress at this period. Progesterone plays a major role in the development, the luteolytic signal and maintenance of regular ovarian cycles. Therefore, progesterone can probably inhibit the development of the luteolytic mechanism until endometrial progesterone receptor activity is lost [26]. However, more studies are required to ascertain the effect of undernutrition on the endocrine changes occurring in the Red Sokoto doe through gestation to early lactation.

In conclusion, this study demonstrates that ration $\mathrm{C}$ elicited as much favourable response in the birth weight and liveweight of Red Sokoto kids, the daily milk yield of their dams as the conventional concentrate ration A which may be too expensive for the local farmer to purchase. Furthermore, in this experiment, the ration differences did not affect plasma progesterone concentration and profile during late gestation through early lactation.

\section{ACKNOWLEDGEMENTS}

The authors gratefully acknowledge the support of the International Atomic Energy Agency (IAEA) Vienna, Austria in funding this project through provision of the hormonal assay kits and chemical reagents. The technical assistance in ELISA protocols by Mr. Joe Iyayi of the Animal Reproduction Laboratory, NAPRI, ABU Zaria, is appreciated. We are grateful to the Director of the National Animal Production Research Institute, Ahmadu Bello University Shika-Zaria for permission to publish this work.

\section{REFERENCES}

[1] Adu IF, Buvanendran V, Lakpini CAM. The reproductive performance of Red Sokoto goats in Nigeria. J Agric Sci (Camb) 1979, 93: 563-566.

[2] Alawa JP, Umunna NN. Alternative feed formulation in the developing countries: Prospects for utilisation of agro-industrial byproducts. J Anim Prod Res 1993, 13: 63-98.

[3] Lakpini CAM, Balogun BI, Alawa JP, Onifade OS, Otaru SM. Effects of graded levels of sundried cassava peels in supplement diets fed to Red Sokoto goats in the first trimester of pregnancy. Anim Feed Sci Technol 1997, 67: 197204.

[4] AOAC. Association of Official Analytical Chemists. Official Methods of Analysis, 13th Ed, Washington DC, USA, 1980.

[5] Goering HK, Van Soest PJ. Forage fibre analysis (apparatus, reagents, procedures and some 
applications). Agricultural Handbook 379, ARS, USDA, Washington DC, 1970.

[6] Kubasik NP, Hallauer GD, Brodows RG. Feeding alternatives to small ruminants. Clin Chem 1984, 30: 284-290.

[7] SAS. Statistical Analysis System. SAS Institute, Cary, North Carolina, USA, 1987.

[8] Swan H, Lamming GE. Studies on the nutrition of ruminants: II. The effect of crude fibre in maize-based rations on the carcass composition of Friesian steers. Anim Prod 1967, 9: 203-208.

[9] McDonald P, Edwards RA, Greenhalgh JFD. Animal Nutrition, 4th Ed, Longman Scientific and Technical, England, UK, 1988.

[10] Silva AT, Orskov ER. The effect of five different supplements on the degradation of straw in sheep given untreated barley straw. Anim Feed Sci Technol 1988, 19: 289-298.

[11] Ikhatua UI, Adu IF. A comparative evaluation of the utilization of groundnut haulms and Digitaria hay by Red Sokoto goats. J Anim Prod Res 1984, 4: 145-152.

[12] Alhassan WS, Ehoche OW, Adu IF, Obilara TA, Kallah MS. Crop residue potential of agricultural development projects: Nutritive value and residue management. NAPRI Annual Report, National Animal Production Research Institute, Shika, Nigeria, 1984, p 35-45.

[13] Ahmed MMM, El Hag FM, Wahab FS, Salih SF. Feeding strategies during summer for lactating desert goats in a rain-fed area under tropical conditions. Small Rumin Res 2001, 39: 161-166.

[14] Kirkpatrick R, Akindele ZT. Reproduction in West African Dwarf goats. J Anim Sci 1974, 39: 163-167.

[15] Mba AU, Boyo BS, Oyenuga VA. Studies on the milk composition of West African Dwarf, Red Sokoto and Saanen goats at different stages of lactation. J Dairy Res 1975, 42: 217226.

[16] Ehoche OW, Buvanendran V. The yield and composition of milk and pre-weaning growth rate of Red Sokoto goats in Nigeria. World Rev Anim Prod 1983, 19: 19-24.

[17] Osinowo OA, Abubakar BY. Appropriate breeding strategies for small ruminant pro- duction in West and Central Africa. OAU/ IBAR, Nairobi, Kenya, 1988.

[18] Sibanda LM, Ndlovu LR, Bryant MJ. Effects of a low plane nutrition during pregnancy and lactation on the performance of Matebele does and their kids. Small Rumin Res 1999, 32: 243-250.

[19] Adu IF, Lakpini CAM. The utilisation of dried poultry as protein supplement for growing Yankasa sheep. J Anim Prod Res 1983, 3: 49-56.

[20] Adu IF, Lakpini CAM. Effect of feeding chopped and unchopped groundnut haulms ("Harawa") on nutrient utilisation and the production of rumen metabolites in Yankasa lambs. Nigerian J Anim Prod 1983, 10: 110 113.

[21] Garmo TH. Dairy goat grazing on mountain pasture. I. Effect of supplementary feeding. Landbzukshwegsk 1986, 241: 1-19.

[22] Akinsoyinu AO, Tewe OO, Ngere LO, Mba AU. Milk composition and yield of the Red Sokoto (Maradi) goats. Dairy Sci Abstr 1982 43: 83-84.

[23] Malau-Aduli BS, Eduvie L, Lakpini C, Malau-Aduli AEO. Chemical compositions, feed intakes and digestibilities of crop-residue based rations in non-lactating Red Sokoto goats in the subhumid zone of Nigeria. Anim Sci J 2003, 74: 89-94.

[24] Malau-Aduli BS, Eduvie L, Lakpini C, Malau-Aduli AEO. Variations in liveweight gains, milk yield and composition of Red Sokoto goats fed crop-residue-based supplements in the subhumid zone of Nigeria. Livest Prod Sci 2003, 83: 63-71.

[25] Malau-Aduli AEO, Anlade YR. Comparative study of milk compositions of cattle, sheep and goats in Nigeria. Anim Sci J 2002, 73: 541-544.

[26] Meyer HHD, Mittermeier T, Schams D. Dynamics of oxytocin, oestrogen and progestin receptors in the bovine endometrium during the oestrous cycle. Acta Endocrinol 1988, 118: 96-104.

[27] Alderman G. Prediction of the energy value of compound feeds. in: Haresign W, Cole DJA (Eds), Recent advances in animal nutrition. Butterworths, London, UK, 1985. 